https://doi.org/10.18485/bogoljub_stankovic.2018.ch14

811.161.1:811.163.4'37

СРЂАН ПЕТРОВИЋ*

Универзитет у Београду

Филолошки факултет

Катедра за славистику

\title{
ДОПРИНОС ПРОФЕСОРА БОГОЉУБА СТАНКОВИЋА ЛЕКСИКОГРАФСКИМ ПРОУЧАВАЬИМА РУСКОГ И СРПСКОГ ЈЕЗИКА
}

\begin{abstract}
У раду се дају преглед и валоризација научноистраживачког опуса проф. др Богољуба Станковића из области лексикографије руског и српског језика. Сагледавају се релевантна питања и проблеми које је професор решавао у својим студијама или за чијим је решењем трагао. На тај начин представљају се најважнији резултати Станковићевих лексикографских проучавања и анализира њихов допринос развоју и унапређивању практичне лексикографије, као и лексикографске теорије у славистичким оквирима.
\end{abstract}

Кључне речи: Богољуб Станковић (1938-2011), лексикографија, конфронтациона истраживања руског и српског језика, двојезични речници, руско-српска лексикографија, српско-руска лексикографија

\section{Srđan Petrović}

\section{THE CONTRIBUTION OF PROFESSOR BOGOLJUB STANKOVIĆ} TO RESEARCH IN LEXICOGRAPHY OF RUSSIAN AND SERBIAN

This paper gives an overview and valorisation of scientific research works of professor Bogoljub Stanković from the field of lexicography of the Russian and Serbian languages. The relevant questions and problems that the professor has solved in his studies or for whose solution he has been seeking have been examined. In this way, the most important results of Stanković's lexicographic studies are presented and their contribution to the development and improvement of practical lexicography, as well as lexicographic theory in the Slavic framework is analysed.

Key words: Bogoljub Stanković, lexicography, contrastive studies of Russian and Serbian language, bilingual dictionaries, Russian-Serbian lexicography, Serbian-Russian lexicography

\footnotetext{
*s srdjan.petrovic@fil.bg.ac.rs
} 
Увод. Истраживања историјског карактера, као што је познато, имају посебан значај за методологију науке. Лингвистичка славистика у том погледу није изузетак. Проучавање њеног историјата нарочито је важно како за адекватну перцепцију, тако и њен даљи развој. У ред релевантних подручја сродних истраживања несумњиво се сврстава приказивање делатности и доприноса истакнутих посленика славистичке мисли. Међу њих свакако можемо прибројати и проф. др Богољуба Станковића, чијим ћемо се доприносом са становишта лексикографије детаљније бавити у овом раду.

Иако је дело професора Станковића у значајној мери везано за русистику, његову ужу научну област, сагледавање професоровог свеукупног доприноса искључиво из потоњег угла ипак не би било потпуно. Као човек несвакидашње енергије, радиности, способности, заноса и љубави према словенству, он је оставио изузетан траг у далеко ширим, славистичким оквирима. О ширини тог доприноса може сведочити и чињеница да се може посматрати најмање из четири угла: наставног, научног, организационог и издавачког. Богољубу Станковићу посвећена је XVI књига часописа Славистиика, чији је вишегодишњи главни уредник и оснивач у сложеним приликама деведесетих година прошлог века био управо он. У одређеном броју чланака у поменутој књизи расветљавају се различити аспекти Станковићевог славистичког дела, његов допринос проучавању асиндетизама и конституисању нишке русистике ${ }^{1}$. Лексикографско наслеђе Богољуба Станковића до сада је углавном сагледавано парцијално, у контексту његовог славистичког опуса, док се у српској лингвистичкој русистици најдаље отишло у анализи његових речника у области школске лексикографије ${ }^{2}$. Допринос лексикографији руског и српског језика из угла научноистраживачког опуса професора Станковића, према нашем сазнању, до сада није представљао предмет засебних проучавања, стога ћемо датој теми овом приликом посветити више пажње. Грађу за анлизу чиниће монографије и научни радови Богољуба Станковића из области лексикографије, односно, уже посматрано, словенске двојезичне лексикографије чији су објекти руски и српски језик. Оцене, напомене и закључци које ћемо износити у одељцима који следе

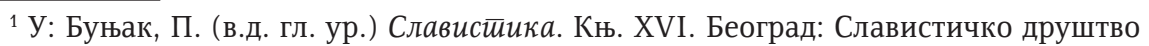
Србије, 2012. в. Буњак, П. „50. скуп слависта у знаку сећања на Богољуба Станковића”, стр. 61-65; Терзић, Б. „Неуморни прегалац на пољу славистике (Проф. др Богољуб Станковић, 1938-2011)”, стр. 17-20; Танасић, С. „Допринос Богољуба Станковића проучавању асиндетизма”, стр. 54-60; Лаиновић Стојановић, Н. „Допринос проф. др Богољуба Станковића развоју нишке русистике", стр. 42-53.

${ }^{2}$ Исп. Павловић-Шајтинац, Маја В. Лексикоірафија школских речника рускої језика у срйској и хрвайској иоворној и соииокулитурној среgини. Необјављена докторска дисертација. Београд: Филолошки факултет Универзитета у Београду, 2016. 
односе се само на радове Богољуба Станковића који се налазе у списку цитиране литературе на крају датог рада.

ЗНАЧАЈ СЕДАМДЕСЕтих годинА. Ради адекватне перцепције и бољег разумевања лексикографских проучавања професора Станковића, осврнућемо се најпре на време које је умногоме одредило његово лекскикографско дело у целини.

Наиме, од седамдесетих година XX века, а тачније њихове друге половине, српска русистика суочила се са извесним променама. Тада долази до видног повећања радова (од академских до научних) у којима се из конфронтационе перспективе обрађује све шири круг питања, што је било условљено развојем лингвистичке славистике, како у целини, тако и на нивоу појединачних њених грана, али и опште лингвистике и теорије конфронтационе анализе исто тако (Пипер 2017: 353). У тим приликама настају први лингвистички радови ${ }^{3}$ Богољуба Станковића, његов магистарски рад (1972) и докторска дисертација (1977) која представља прву монографију у српској лингвистичкој русистици која je доследно конфронтативно конципирана (ibid: 347). И у Станковићевим лексикографским проучавањима видно се запажа конфронтациони приступ. Резултатима конфронтационе анализе, као и њој самој, професор је давао важно место. Он је резултате конфронтационих проучавања сматрао изузетно битним за лексикографску делатност, нарочито приликом израде двојезичних речника. То је често истицао у својим лексикографским истраживањима (нпр. Станковић 1999љ: 8, Станковић 1999в, Станковић 1999д, Станковић 1999г, Станковић 1999а: 94-95, Станковић 1999и: 109, Станковић 1999л: 131-132), али и примењивао у својим ауторским и ауторско-редакторским лексикографским остварењима, што је далеко значајније. У лингвистичким радовима, чак и када нису били везани за лексикографију, Станковић је истицао да добијени резултати могу имати лексикографске импликације и на тај начин допринети потпунијем и адекватнијем успостављању коресподентности у преводној лексикографији (нпр. Станковић 2000: 1083).

Период седамдесетих година значајан је и за почетке лексикографског рада Богољуба Станковића, озбиљније бављење лексикографијом и његов непосредан рад на састављању речника. Крајем шездесетих година Ђорђе Јазић покренуо је пројекат који је за циљ имао израду рускосрпскохрватског речника. Станковић је у њему не само узимао активно учешће, већ га успешно и завршио. Како сазнајемо из предговора другог

\footnotetext{
${ }^{3}$ O одређеним лингвистичким темама, у првом реду лексиколошким и синтаксичким, Станковић је писао и крајем шездесетих година, међутим, карактер тих радова углавном се одликује снажно израженом лингводидактичном димензијом (исп. Буњак, Голубовић 2012: 29)
} 
и допуњеног издања Руско-срӣскої речника (Станковић 1998: 5), 1969. године отпочиње сарадња издавачке куће „Руски језик” из Москве и Матице српске из Новог Сада у оквиру заједничког пројекта израде руско-српскохрватског речника. Све знање и искуство које је стицао током рада на пројекту Станковић је користио у изради будућих речника и радова у којима је расветљавао низ питања из области теоријске и практичне лексикографије. Плодотворност тог периода за професорову лексикографску делатност може илустровати и податак да свој први речник он објављује већ 1979. године, а други коју годину касније (в. напомену 7 овог рада).

ТЕоријско-мЕтодолошки приступ. У својим лексикографским истраживањима, као што смо навели, професор Станковић сагледавао је различита питања у значајној мери из конфронтационе перспективе, превасходно сучељавајући руски и српски језик. Приликом теоријског заснивања конфронтационе анализе ослањао се на диференцијални метод Радована Кошутића. Дати метод, који се у основи много не разликује од метода који данас називамо конфронтационим (или конфронтативним), огледа се у системском и поступном приступу поређења оних елемената и појава у блискосродним језицима (овде: руском и српском) код којих се може манифестовати интерференција приликом усвајања, и то на свим нивоима од фонетско-фонолошког до синтаксичког, укључујући и лингвокултуролошки план. Професор Кошутић, као бриљантан слависта чији је допринос развоју и утемељењу руско-српске лексикографије изузетно велики, својим наслеђем умногоме је утицао на Богољуба Станковића. У својим радовима он се на Р. Кошутића неретко позивао, неке је чак и посвећивао додатном расветљавању његовог теоријско-методолошког приступа ${ }^{4}$. На тај начин он је додатно утемељио конфронтациону анализу руског и српског језика, а затим је и даље примењивао у свом опусу, што се запажа и из фундаменталне и из апликативне перспективе.

У својим истраживањима професор Станковић често се ослањао на сазнања и достигнућа руске лексикографије (дескриптивне и двојезичне ${ }^{5}$ ) и руске лексиколошке школе (нпр. на В. В. Морковкина), уз веома добру обавештеност и о достигнућима словенске лексикографије. Посебно бисмо издвојили наслеђе Л. В. Шчербе и идеју о активном речнику (и активној граматици) коју је ангажовано заступао не само он већ

${ }^{4}$ У некима од њих унеће и сасвим нови поглед на приступ Радована Кошутића и његову рецепцију у српској послератној русистици (исп. Кончаревић 2010: 329-330).

${ }^{5}$ Код двојезичне лексикографије најпре имамо на уму руско-француску и француско-руску: Русско-франиузский словарь (под общим руководством и редакцией Л. В. Щербы), Москва, 1936. Франиузско-русский словарь активного типа (под ред. В. Г. Гака и Ж. Триомфа), Москва, 1991. 
и В. Г. Гак. На Станковића је видно утицала и теорија језика у контакту, а понајпре В. Ј. Розенцвајг, што се јасно уочава у професоровом поимању појма билинівизам (исп. нпр. Станковић 1999б).

Формирање концептуалног приступа Богољуба Станковића у погледу различитих лексикографскимх питања и састављања двојезичних речника било је одређено, између осталог, његовом методологијом проучавања и методиком наставе словенских језика као инословенских - најпре руског, а затим и српског (више о томе у: Станковић 2010б, Кончаревић 2018). У образовном систему, рачунајући све нивое образовања, Станковић је провео безмало 45 година. Тако се током каријере остваривао и као практичар, стога не чуди зашто су његова истраживања неретко писана у оквирима примењене лингвистике и била оријентисана на методику наставе. Са лексикографским истраживањима то је такође био случај. Дата веза испољава се и у Станковићевом ставу да је сваки општи двојезични речник, у условима наше средине, умногоме наставног карактера (Станковић 1999е: 42), док је за школске речнике то сасвим очигледно. Како је професор пишући о речницима писао управо о општој и школској лексикографији, све постаје још јасније.

БоГОљУБ СТАНКОВИЋ и ЛЕКСИКОГРАФИЈА. Станковићево ЛеКсикографско наслеђе може се сагледати из двају углова: 1) на примеру његових студија из области теоријске и практичне лексикографије, 2) на примеру његових речника. Иако би дате целине могле деловати као релативно засебне, професор Станковић их је видео као две стране једне целине. Он је с правом домете словенске лексикографије директно повезивао са дометима и резултатима конфронтативних истаживања словенских језика. Станковић је истицао потребу и значај научно заснованих речника, а не механички састављених (Станковић 1999љ: 8-9, Станковић 1999л: 131-132). Говорећи о њиховој изради, он не би употребљавао реч

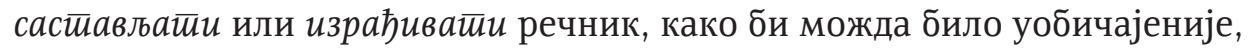

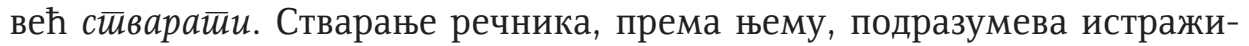
вање које ће и претходити раду на речнику и тећи паралелно са тим радом, чиме се јасно види поменута повезаност горенаведених целина (в. Станковић 1999љ: 7).

Станковићево опредељење за лексикографију није било случајно. О томе на јасан начин сведочи и он са̂м у раду уместо предговора својим Лексикоїрафским оїлеgима: „Опредељујемо се за ову област због непобитне чињенице да без добрих двојезичних словенских речника нема успешног усвајања инословенских језика у другој словенској средини нити правог културног и духовног повезивања, а истовремено се опредељујемо и у жељи да скромно допрнесемо научној афирмацији тог рударски мукотрпног језикословног посла који је још увек од необавештених и 
лошенамерних потцењен, а од профитера злоупотребљен" (Станковић 1999љ: 5).

За живота Богољуб Станковић објавио је седам речника, од чега један припада општој лексикографији ${ }^{6}$, а шест школској ${ }^{7}$. Изузимајући Руско-срйски и срйско-руски речник : за среgюу школу, који је објављен

${ }^{6}$ Русско-сербскохорватский словарь : около 52000 слов / под редакцией Боголюба Станковича; [словарь составил коллектив авторов Д. Вигневич, С. Даничич, М. Дугонич-Радич, В. Йовин, В. Косанович, Р. Крунич, М. Пупавац, Д. Райкович, Я. Савич, Б. Станкович, Бр. Станкович, Л. Тинтор, Дж. Язич]. - Москва: Русский язык ; Нови Сад: Матица српска, 1988. - 984 стр. А затим и наредна издања, сада већ под називом: Руско-срйски речник : 55.000 речи / у редакцији Богољуба Станковића ; [речник је саставио колектив аутора Д. Вигњевић, С. Даничић, М. Дугоњић-Радић, В. Јовин, В. Косановић, Р. Крунић, М. Пупавац, Д. Рајковић, Ј. Савић, Б. Станковић, Бр. Станковић, љ. Тинтор, Ђ. Јазић]. - 2. исправљено и допуњено изд. - Нови Сад: Матица српска, Будућност ; Москва: Русский язык, 1998. - 1001 стр. Изд.: 1999, 2008, 2009. Руско-срйски речник. - 2. допуњено изд. - Нови Сад : Прометеј, 1999. - 1001 стр. - (Библиотека Речници); Рускосрйски речник. - 3. допуњено изд. - Нови Сад : Прометеј, 2008. - 1001 стр. - (Библиотека Речници); Руско-срйски речник. - 4. допуњено изд. - Нови Сад : Прометеј, 2009. - 1001 стр. - (Библиотека Речници)

${ }^{7}$ Реиник рускоі̄ језика : за основну школу. - 1. изд. - Београд : Завод за уџбенике и наставна средства, 1979. - 147 стр. Изд.: 1979, 1982, 1984, 1985, 1987, 1988, 1990, 1991, 1992, 1994, 1998. Реиник рускої језика : за основну школу. - 2. изд. - Београд : Завод за уџбенике и наставна средства, 1979. - 147 стр. Реиник руской језика : за основну школу. - 3. изд. - Београд : Завод за уџбенике и наставна средства, 1982. - 132 стр. Речник рускої језика : за основну школу. - 4. изд. - Београд : Завод за уџбенике и наставна средства, 1984. - 132 стр. Реиник рускої језика : за основну школу. - 5. изд. - Београд : Завод за уџбенике и наставна средства, 1985. - 13, 132 стр. Речник руской језика : за основну школу. - 6. изд. - Београд : Завод за уџбенике и наставна средства, 1987. - 13, 132 стр. Речник рускої језика : за основну школу. - 7. изд. - Београд : Завод за уџбенике и наставна средства, 1988. - 13, 132 стр. Речник руской језика : за основну школу. - 8. изд. - Београд : Завод за уџбенике и наставна средства, 1990. - 13, 132 стр. Реиник рускої језика : за основну школу. - 9. изд. - Београд : Завод за уџбенике и наставна средства, 1991. - 13, 132 стр. Речник руской језика : за основну школу. - 10. изд. - Београд : Завод за уџбенике и наставна средства ; Нови Сад : Завод за издавање уибеника, 1992. - 13, 132 сйр. Речник рускоі језика : за основну школу. - 11. изд. - Београд : Завод за уџбенике и наставна средства, 1994. - 143 стр. Речник руской језика : за основну школу. - 12. изд. - Београд : Завод за уџбенике и наставна средства, 1998. - 143 стр. Школски руско-срйскохрвайски речник : среgюи ниво учења. - Београд : Завод за уџбенике и наставна средства, 1983. - 339 стр. Школски руско-срӣски речник : среgюи ниво учења. - Београд : Завод за уџбенике и наставна средства, 1992. - 336 стр. Изд.: 1995, 1998. Школски руско-срйски речник : среgюи ниво учења. - 2. изд. - Београд : Завод за уџбенике и наставна средства, 1995. - 336 стр. Школски руско-срӣски речник : среgюи ниво уиења. - 3. изд. - Београд : Завод за уџбенике и наставна средства, 1998. - 336 стр. Руско-срйски реиник : за основну школу. - Београд : Завод за уџбенике и наставна средства, 1999. - 338 стр. Изд.: 2002. Руско-срйски речник : за основну школу. - 2. изд. - Београд : Завод за уџбенике и наставна средства, 2002. - 338 стр. Руско-срйски и срӣско-руски речник : за основну школу. - Београд : Завод за уџбенике и наставна средства, 2004. - 696 стр. Изд.: 2009. Руско-срйски и срйско-руски речник : за основну школу. - 2. изд. - Београд : Завод за уџбенике и наставна средства, 2009. - 696 
пред професорову смрт 2011. године, сваки Станковићев речник доживео је више издања, а Речник рускої језика : за основну школу чак дванаест (више о његовим руско-српским школским речницима у: Станковић 1999м).

Професор Станковић се лексикографијом бавио више од четири деценије. Према нашој оцени, најпродуктивнији период његов за лексикографски опус јесу осамдесете и дведесете године прошлог века. У њему је обрађивао различите врсте питања, од општих преко конкретнијих до сасвим конкретних, теоријског и практичног карактера. Богољуб Станковић у радовима настојао је да опише језичке појаве на што исцрпнији начин. Стално је пратио промене у језику и настојао да његово лексикографско наслеђе у том погледу не заостаје, већ буде прилагођено потребама савременог доба, корисника и науке о језику. Нова издања својих речника уредно је допуњавао. Закључке у радовима обично није кориговао. Својих позиција се углавном држао, евентуално би их само даље разрађивао и прецизирао, старе примере допуњавао новим, још потпунијим, на тај начин их заокружујући.

Своја најзначајнија лексикографска истраживања Богољуб Станковић објединио је у Лексикоірафске оілеgе, своје капиталну студију из области лексикографије (Станковић 1999). Она представља плод професоровог вишедеценијског бављења овом облашћу. Како је у њу уврстио своја истраживања настала до 1999. годин, дата студија може послужити као поуздан извор за проучавање двојезичне лексикографије XX века, а у првом реду руско-српске и српско-руске. У Оіллеguма Станковић нуди теоријски и практични одговор на многа питања лексикографске теорије и праксе, одговор који би имао пројектни карактер а пуну реализацију у у виду двојезичних речника. Читајући Оілеgе може се запазити да у појединим радовима одговора и нема, будући да је Станковић одређеним питањима приступао као дилеми коју треба разрешити. То свакако не би требало карактерисати као мањкавост, јер је познато да се у науци до поузданог одговора углавном не долази брзо, а некад одговор није одмах ни потребан, док покретање теме само по себи може представљати значајан корак. Такође, Станковић је истакао поједина питања која су остала изван његових разматрања у Лексикоіррафским оїлеguма, али која свакако заслужују пажњу истраживача (нпр. питање нормативне недефинисаности, варијантност и дублетност облика итд.).

Након Оїлеgа Станковић није много писао о лексикографији. Објавио је свега три таква рада (Станковић 2002, Станкович 2004, Станковић 2010a), док би тај број могао бити и већи уколико бисмо узимали у об-

стр. Руско-срйски и срӣско-руски речник : за среgюу школу / Богољуб Станковић. - Београд : Завод за уџбенике, 2011. - 459 стр. 
зир радове који лексикографску димензију садрже као пропратну (нпр. Станковић 2003). Са друге стране, током двехиљадитих година Станковић је објавио чак два нова школска речника. Један 2004. намењен за основношколски ниво, а други 2011. године, пред крај свог живота. У питању је Руско-срйски и срйско руски речник: за среgюу школу који у нашој школској лексикографији представља најамбициозније замишљен дидактички руско-српски и српско-руски речник и свакако један од најкомпЛексијих У овом домену.

ЛЕКСИКОГРАФСКА СУЧЕљАВАњА РУСКОГ И СРПСКОГ ЈЕЗИКА. СТањЕ У ЛЕКСИкографији словенских језика, према проф. Станковићу (1999љ: 5-6), умногоме је детерминисано стањем билингвизма контактних језика који представљају њен објекат. Током друге половине XX века међусловенско и српско-руско двојезичје достигло је свој зенит, што је у условима повећаног интересовања за руским језиком и повољног положаја руског језика у нашем образовном систему нашло одраз и у области лексикографије. Већ коју деценију касније ситуација се мења. Међутим, и упркос томе што је крај прошлог века карактерисала далеко непогоднија ситуација за развој двојезичне лексикографије, најзначајније домаће научне институције и издавачке куће смогле су снаге да издају значајна славистичка остварења ${ }^{8}$. Сумирајући актуелно стање међусловенске лексикографије крајем XX века, Станковић је закључио следеће: превасходно су заступљени речници у којима је српски језик преводни, а неки други словенски језик (у Станковићевој терминологији - инословенски) полазни, и то најпре руски, по обиму грађе мањи или средњи, док се са становишта карактера дати речници могу квалификовати као општи, терминолошки и школски (Станковић 1999љ: 7).

Повољан период за развој словенске лексикографије створио је добре услове за реализацију заједничког пројекта издавачке куће „Руски језик" из Москве и Матице Српске из Новог Сада. Њихова успешна сарадња резултирала је издавањем речника под називом Русско-сербскохорвайский словарь (1988) у редакцији Богољуба Станковића. Од другог издања овај волуминозни речник издаје се под назовом Руско-срйски реиник (1998). Његов значај огледа се у томе што је у њега у највећој мери инкорпорирано тадашње знање и достигнућа до којих се дошло у русистици и славистици, нарочито у погледу конфронтационих истраживања. Руско-срйски реиник и сада представља незаобилазан лексиког-

\footnotetext{
${ }^{8}$ Нпр. вишеденијски подухват САНУ успешно је резултирао објављивањем двотомних изања Пољско-срйски речник = Słownik polsko-serbski. Том 1, A-Ó / Том 2, P-Ż (1999, 2001) и Чешко-срӣски речник = Česko-srbský slovník. Том 1, А-O / Том 2, P-Ż (2000, 2001), оба у издању САНУ и Завода за уџбенике и наставна средства, док је Матица Српска објавила Руско-срйски речник, друго и допуњено издање, у редакцији управо професора Станковића (1998).
} 
рафски извор који се активно користи не само у настави руског језика и превођењу, већ и приликом спровођења научних истраживања руског и српског језика, лексикографских и других. Из тог разлога не чуди зашто је овај речник добио високе оцене у научној и стручној јавности. Данас, готово две деценије касније, осврћући се на резултате савремене руско-српске двојезичне лексикографије, српска русистика и руска србистика не могу избећи у одређеној мери забрињавајућу чињеницу да се од Руско-срйскої реиника у редакцији Богољуба Станковића, имајући у виду референтне руско-српске речнике општег типа, даље готово није отишло.

Убрзо након успешне реализације првог пројекта и издавања значајног руско-српскохрватског речника уследио је наставак рада и покретање нове сарадње. И овога пута у питању је био заједнички пројекат између Матице Српске и московског „Руског језика”, само сада, као логични наставак, под називом Срйскохрвайско-руски реиник. Рад на датом пројекту, нажалост, није завршен. Обустављен је 1992. године услед неповољних прилика које су тада настале и након тога више није поново покретан (детаљније у: Станкович 2004).

Прекидање рада на потоњем пројекту није значило и прекидање Станковићевог интересовања за српско-руску лексикографију. Посебну пажњу у својим радовима он је посвећивао двојезичним речницима са српским језиком као полазним. Сматрамо да је то чинио с правом, будући да је одсуство датих речника српској двојезичној лексикографији (било) веома уочљиво. Богољуб Станковић је о томе више пута писао како у Лексикоірафским ойлеgима (Станковић 1999љ: 7), тако и у каснијим радовима (Станкович 2004: 294-295, Станковић 2010а: 191) ${ }^{9}$. Зато је професор Станковић (1999љ: 7) српско-руске речнике сматрао примарним задатком наше савремене лексикографије ${ }^{10}$. Они заузимају посебно место у његовом лексикографском опусу, на шта може указати и податак да су радови настали након Лексикоірафских оіллеgа углавном посвећени српско-руској лексикографији (Станкович 2004, Станковић

${ }^{9}$ Оно што даје позитивне наговештаје у погледу попуњавања празнине у српскоруској лексикографији јесте објављивање Срйско-рускої речника Радослава Бошковића у издању београдског Јасена. Дати речник појавио је 2013. године и садржи око 55000 речи.

${ }^{10}$ То што је Станковић израду речника са полазним српским језиком видео као значајне свакако не значи да је друге типове речника (нпр. специјалне) он сматрао мање важним. Он је као битне задатке словенске лексикографије у том погледу видео: актуелизацију, осавремењавање и допуњавање постојећих руско-српских речника (школских, општих и терминолошких), размишљање на састављању великог руско-српског речника (дво- или вишетомног), наставак лексикографског сучељавања терминолошких система српског и других словенских језика, на примерима из различитих области (Станковић 1999љ: 7). 
2010а). Њом се бавио до краја живота. Након професорове изненадне смрти 2011. године, остала је драгоцена грађа коју је прикупљао и обрађивао за нови српско-руски речник. Зато ћемо се у следећем одељку рада више осврнути на то питање, а наредним одељцима и на друга релевантна питања из Станковићевих лексикографских истраживања.

КОНЦИПИРАњЕ И САСТАВЉАњЕ СРПСКО-РУСКОГ РЕЧНИКА. КОНСТСТУЈУћИ изразито одсуство српско-руских речника у домаћој лексикографији, Станковић је већу пажњу посвећивао састављању и конципирању речника са српским језиком као полазним. Како је наводио, разлога су два: 1) за говорнике српског језика они би били активног типа и омогућавали им активан проступ инословенском језику и његовом интензивнијем усвајању, 2) за сваког странца који треба да почне да учи српски језик они представљају незаобилазну књигу (Станковић 1999љ: 7). Потенцијални српско-руски речник Станковић је видео као базични школски речник општег типа, средњег обима у којима се сучељвају српски и руски језик, а који би потом могли да послуже као модел за друге српско-инословенске речнике (ibid).

Пре него што би се приступило лексикографској преводној семантизацији, најактуелнији задаци везани за базични српско-руски речник, према Станковићу (1999љ: 7-8), јесу утврђивање списка базичне лексике (обим: око 5000 речи) и инвентарисање начина на који функционишу у говорној етикецији и приликом реализације говорних чинова и интенција у свакодневној комуникацији. Рад на том речнику подразумевао би примену постојећих резултата конфронтационе анализе, као и решавање других задатака и питања међу којима се као најважнији издвајају следећи: „а) инвентарисање српских неологизама и успостављање еквивалентности са стилистички адекватним лексемама у руском језику, б) одабир и преводна семантизација терминолошке лексике (нарочито услед њеног значајног уплива у словенске језике, чак толиког да се многи термини већ тако и не дожиљавају), в) утврђивање актуелних стилистичких карактеристика лексема и успостављање стилистички адекватне еквивалентности, г) идентификација српске лексике која у својој семантици садржи национално-културну компоненту и изналажење најадекватније семантизације на руском језику, д) проучавање структура функционалних речи и њихово синтаксичко представљање у речнику, ђ) конфорнтационо проучавање лексичке и синтаксичке спојивости од српског ка руском и њихово максимално могуће лексикографско приказивање" (Станковић 1999љ: 8).

СинтАгмАтикА. Бављење синтагмама није била само једна од различитих тема којима је у својим радовима Богољуб Станковић посвећивао пажњу. Она представља једно од централних подручја његовог интересовања и самим тим заузима видно место у његовом лингвистичком на- 
слеђу. Синтагмама је професор посветио своју докторску дисертацију и током свог радног века о њима је често писао (Станковић 1979). Будући да се синтагме заснивају не само по правилима синтаксичке спојивости већ и лексичке, јасно је да за њих заинтересована и лексикографија. Станковић је писао о њима и са тог становишта.

Анализирајући стање почетком деведесетих година и најновија лексикографска остварења у којим су примењена нова сазнања конфронтационих истраживања, Богољуб Станковић (1999г: 34) наводи да су на најсистематичнији и најпотпунији начин представљена диференцирања на нивоу глаголских синтагми заснованих на рекцијској вези. Њихово изостајање или маргинално представљање бележи се код лексикографског описа односа на нивоу субстантивних и адјективних синтагми чије се заснивање врши на рекцијској вези и синтагми заснованих на прикључењу. Он запажа да су синтагматски односи нарочито у српскоруској лексикографији маргинално представљени, стога синтагме српског језика види као једну од примарних области конфронтационе анализе, и то синтагме одредбених односа. (ibid). Уз то, треба имати на уму сазнања постојећих истраживања да „диференцирања између српског и руског језика у области синтагматике нису на нивоу синтагматских модела, већ на нивоу лексичке конкретизације, што само по себи чини да се синтагматски односи два језика најпотпуније могу представити управо лексикографским средствима тј. у речницима различитих типова - како у посебним синтагматским речницима општег или специфичног карактера, тако и у свим другим преводним речницима" (Станковић 1999г: 34-35). У своме раду „Конфронтациони приступ синтагмама српског и руског језика са становишта двојезичне лексикографије" професор је показао како је код лексикографске обраде синтагми потребно водити рачуна о узајамној повезаности лексичке и синтаксичке спојивости (детаљније у: Станковић 1999г: 35-39). Анализу је спровео на примеру српских одредбених синтагми које у позицији главне компоненте садрже лексеме йреgузеће, фабрика и инgустирија и одговарајућих руских еквивалената.

ПоврАтни глАголи. На ширем корпусу двојезичних речника, српско-руских и руско-српских, Богољуб Станковић бавио се степеном заступљености и питањима семантизације повратних глагола у руском и српском језику. Приликом истраживања он се ограничио на речнике средњег обима и уочио стање које би се на прегледан начин могло свести на следеће: 1) глаголи са рефлексивним, реципрочним и медијалним значењем се превасходно укључују и семантизују, 2) маргинално се то чини код повратних глагола са квалификативним, модалним и безличним значењем, 3) случајеви када се помоћу повратних глагола исказује пасивно значење сасвим се изоставља (Станковић 1999е: 42). 
Анализирани речници ослањали су се на приступ традиционалне лингвистике према ком се глаголске конструкције са морфемом се анализирају значењски, без оштрог разграничавања лексичко-семантичког и синтаксичког нивоа. То је и утицало да се приликом одабира повратних глагола који ће бити лексикографски обрађени и семанизовани „остајало на лексемама и значењима очигледним и несумњивим на лексичком плану, а занемаривана су или апсолутно изостављана значења која се реализују у синтаксичкој конструкцији" (Станковић 1999е: 41-42). Професор Богољуб Станковић, као практичар са дугогодишњим стажом у настави, разумео је да у нашој средини готово сваки општи двојезични речник има у великој мери наставни карактер, те као такав, уз што интегралнији лексикографски опис речи, далеко више може допринети развијању језичке продукције (а не само рецепције) и користити приликом процеса превођења. Он је сматрао и да српска једнојезична лексикографија све више треба да се ослобађа лингвоцентризма и креће ка антропоцентризму, јер ће тиме више помоћи не само развоју двојезичне лексикографије него и двојезичја где један од језика укључује и српски (Станковић 1999е: 49)

Значајан аспект професорових истраживања повратних глагола јесте што он није само запажао, констатовао и описивао постојеће стање, већ укључивао и пројектну димензију истраживања, те предлагао могућа и пожељна решења за будућа речничка остварења. Користећи се резултатима конфронтационе анализе, Станковић је изнео низ корисних сазнања везаних за диференцијалне односе између повратних глагола у руском и српском језику. Нека до њих нису одмах уочљива, нека су на конфронтационом плану сложена и испреплетана, стога нису нашла одраз у претходним лексикографским остварењима, али приликом састављања будућих речника лексикографи свакако треба да се ослоне на њих. У својству примера навећемо одредницу глагола јести се која је представљена у Толстојевом Срйскохрвайско-руском реинику (а) и предлог исте одреднице који је понудио Богољуб Станковић (б) (1999е: 49):

(а) ЈЕСТИ СЕ: 1) быть съеgобным, 2) gослеgовать, раздранаться, нервничать.

(б) JЕСТИ СЕ: 1) квалификативно быть съедобным; Ове печурке се једу = эти грибы съедобные; 2. модално есться; Једу ми се трешње = Ему хочется есть черешни, Ему едятся черешни; 3. неодређено-лично есться; Тамо се тако слатко јело = Там так сладко елось; 4. пасивно а) съеда́ться; Месо се јело сваки дан = Мясо съедалось ежедневно; б) преносно съеда́ться, тра́титься; Лако је док се једу туђе паре = Легко пока съе- 
даются чужие деньги; 5. меgијално кроши́ться; Зуб се једе = Зуб крошится; 6. преносно меgијално пережива́ть, не́рвничать; Он се ужасно једе $=$ Он ужасно переживает; јести се у себи = сам себя есть; 7. преносно реципрочно грызться, ссориться; Јели су се немилосрдно = Они гризлись беспощадно.

Као што се може закључити, у условима двојезичне лексикографије Станковић је тежио достизању што интегралнијег лексичко-синтаксичког описа језика, који би се темељио на резултатима истраживања, у првом реду конфронтационих, али и на основу истраживања до којих би са̂м лексикограф долазио приликом рада на речнику (нарочито у срединама када ниво конфронтационих истраживања није довољан, те је принуђен самостално да их врши). Одреднице попут оних које је предложио Богољуб Станковић заузимале би далеко више простора и зато биле у мањем обиму заступљене у речницима чији је простор по правилу ограничен.

СтилистикА. Бавећи се лексикографском стилистиком, професор Станковић анализирао је информације везане за стилистичку маркираност руске и српске лексике. За истраживања је бирао богати материјал - ауторитативне дескриптивне речнике савременог руског и савременог српског језика, као и преводне речника у об̃ смера. Ипак, мора се приметити да се једнојезичном лексикографијом више бавио него двојезичном, што је и разумљиво будући да дескриптивни речници представљају почетну тачку за питања стилистичких информација у преводним речницима.

Разматрајући наведена питања у речницима руског и српског језика, Станковић (1999j: 52) је уочио три врсте размимоилажења: прва се јавља на нивоу речника двају језика (огледају се у различитом приступу стилистичком раслојавању лексике), друга се запажа у речницима истог језика (неподударност стилистичких информација у једнојезичним речницима), а трећа на примеру истог речника (неистоветна и недоследна стилистичка квалификација истоветне лексичке грађе).

Ситуација која се тиче једног језика требало би да буде простија. Почнимо од ње. У изворима једнојезичне лексикографије, независно од језика (у обама је иста ситуација), уочава се неподударност стилистичких информација. Разлоге за такво стање професор види у различитим теоријским полазиштима речника и променама које се дешавају у временима настајања речника или током њиховог стварања (ibid).

Забележене разлике које се јављају на нивоу двају језика тичу се различитог приступа стилистичком раслојавању лексике. Тако се у, примера ради, уз лексему ајкула у РСАНУ и РМС налази квалификатор зоол., док Велики и Мали акаgемијски реиник рускої језика и Ожеїовљев 
реиник рускої језика не бележе никакву ознаку код речи акула. Или, док у српским речницима лексему амплитуда прати физ., у руским се запажања неусаглашеност - у Великом акаgемијском реинику дата лексема налази се без ознаке, а у Малом са физ. Ипак, и без обзира на то, дате речнике руског језика карактерише виши степен систематизованости и наглашенијег приступа стилистичкој обојености речи, што је последица и далеко веће развијености функционалне стилистике у руској лингвистици (исп. Станковић 1999j: 54-56).

Како двојезични речници свој темељ имају у једнојезичним, те заправо из њих настају, размимоилажење у погледу стилистичких информација унутар једног језика заиста двојезичну лексикографију ставља пред озбиљне дилеме. Како оне могу бити и веће показују недоследности и неусаглашености на нивоу истог речника. То ћемо илустровати примерима из двојезичних речника које Богољуб Станковић наводи у своме раду „Стилистичке информације у речницима српског и руског језика". На пример, у Толстојевом речнику лексеме крајник, рожња-

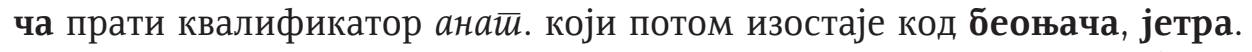
Затим, у Руско-срйскохрвайском реинику у редакцији Б. Станковића уз лексеме ива, ясень можемо наћи квалификатор бой. док га код берёза, верба нема.

Сводећи дата сагледавања, професор наводи да начин одређивања стилистичке и употребне вредности треба другачије организовати у двојезичним речницима него што је то случај у дескриптивним. Он предлаже примену ознака које додатно конкретизују сферу употребе. У преводном речнику стилистичке информације умногоме треба да су „у функцији прецизнијег тумачења и семантизације лексеме полазног језика, па је отуда улога стилистичке напомене да сем указивања на стилистички карактер лексеме и одређивања степена нормативности укаже и на сферу употребе и део реалности којој припада објекат или појава означена тумаченом лексемом" (Станковић 1999j: 60). Професор Станковић је закључио да је стилистичко информисање на систематичнији, прегледнији и актуелнији начин представљено у анализираним речницима руског језика, те да одређена достигнућа руске лексикографске стилистике могу користити приликом стварања једнотомника српског језика, а постојећи преводни речници имати корективну и подстицајну улогу приликом рада на новим речницима.

ВЕЗНИЦИ, ВЕЗНИЧКИ ИЗРАЗИ и ВЕЗНИЧКЕ РЕЧИ. Пишући о ВеЗНИЦИМа, УЗ ослањање на тада постојеће традиције двојезичне лексикографије, Станковић је настојао да изнађе прецизнија, потпунија и систематичнија решења лексикографског описа везника која би могла да нађу примену у новим издањима постојећих речника или у онима који ће се тек појавити, сасвим новим. Иако су везничка средства у руском и српском језику 
у значајној мери слична, са становишта двојезичне лексикографије далеко су интересантнији диференцијални односи међу њима. Професор Станковић (1999а: 90) је издвојио неке од њих: 1) виши степен стилистичке раслојености и разноврсности простих везника у руском језику него у српском, 2) фреквентније и разноврсније образовање сложених везника (везничких израза) у руском језику него у српском, 3) неједнак обим значења и функција конкретних руских везничких речи и њихових српских еквивалената. Приликом ближе анализе везника, везничких израза и везничких речи Богољуб Станковић указао је на одређен број недоследности и пропуста у њиховом лексикографском опису, укључујући различите елементе речничке микроструктуре попут квалификатора, илустративног материјала и др.

Представићемо то неким од примера (ibid): Русско-сербскохорватский словарь бележи већину стилистички маркираних везника који се иначе дају у савременим речницима руског језика, међутим, не указује се на карактер односа који се њима успоставља или се семантизују путем стилистички необележених везника у српском језику (нпр. кабы = кад би, ако би; коли, коль = ако, кад већ; покуда = док, догод, доклегод; якобы = као да). У случајевима када у српском језику није могуће наћи одговарајући преводни еквивалент за стилистички маркирани везник, предлаже се да се макар уз српске неутралне везнике забележи информација о њиховој стилистичкој маркираности (Станковић 1999а: 91). Са друге стране, у Толстојевом Срйскохрвайско-руском реинику Станковић констатује да се стилистички маркирани везници или не бележе (нпр. било, аконо) или се бележе уз следеће недостатке: без одређења стилистичке вредности (нпр. буд, јере, еда), уз неодговарајући еквивалент са становишта стилистике у преводном језику (нпр. дочим $y c \bar{u} .=1$. пока что, 2. между тем как) или уз неадекватан граматички коментар (нпр. нетом је квалификовано као прилог без информације о стилистичкој маркираности уз тумачење как только, лищь только, еgва) (ibid).

Професор наводи да у анализираним речницима лексикографска обрада везника није одговарајућа и упркос високој фреквентности везника. То се уочава и путем недоследности на нивоу указивања карактера односа који се помоћу одређеног везника успоставља између делова конструкције, као и у погледу описа вишесложних везника. Он наводи да је неопходно спровођење системске конфронтационе анализе која би обухватала обиман корпус стилистички разноврсних и разнородних текстова (Станковић 1999а: 94-95).

Предлози. Интересовање за предлоге код Станковића појавило се не само због чињенице да их треба конфронтационо проучавати ради утврђивања односа двају блискосродних језика као што су то руски и српски, већ како би се дошло до одговора на одређена питања у чијем се 
приступу запажа хетерогеност на нивоу граматичких описа наведених језика (нпр. дефинисање предлога, проблем њиховог лексичког значења, затим критеријуми класификације и утврђивања типова предлога где се има у виду заправо питање предлошких израза одн. сложених предлога) (Станковић 1999и: 97).

Иако би се на први поглед могло помислити да изразитих разлика код руских и српских предлога у толикој мери нема, професор Станковић показује да ситуација није таква. Најзначајнија диференцирања, наводи он, манифестују се у овим случајевима: 1) приликом спојивости са падежним облицима (нпр. за у руском језику користи се уз акузатив и инструментал, а у српском и са генитивом приликом изражавања темпоралности, нпр. за живота мога оца - при жизни моего отца), 2) на нивоу семантичке структуре, обима и распореда значења (нпр. уп. руске предлоге $u 3$-за и $u$ - $\bar{u}$ og и српске етимолошке еквивалентне предлоге $u з a$ и ucupeg), 3) затим у погледу лексичке спојивости (уп. рус. в университете, на прогулке и срп. на универзитету и у шетњи), 4) међусобних односа једних предлога према другима у истом језику (нпр. предлози за,

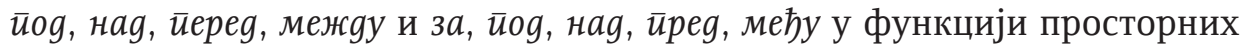
одредби), 5) у фреквенцијској употреби (примера ради, руски предлог $\kappa$ налази се на 4 . месту на списку фреквенције руских предлога, док је српски предлог к у том погледу тек на 17. месту) (дет. исп. Станковић 1999и: 98-105).

Лексикографском обрадом предлога Станковић се бавио у својим радовима (нпр. Станковић 2002), међутим, то је неретко чинио из лингводидактичке перспективе (в. Станковић 1999и, 1999ж). У њима је давао низ предлога за потенцијалне речничке чланаке који могу бити искоришћени и у наставној пракси. У наставку рада навешћемо један од предлога који је у свом раду „Предлози будућем српско-руском школском речнику" понудио Богољуб Станковић (1999ж: 115):

Из йреgл. с їен. 1. у йросиорној оgреgби а) из с їен.; из куће из до́ма, и́з дому; из шуме и́з лесу, из ле́са; допутовати из Београда прие́хать из Белгра́да; извадити из џепа вы́нуть из карма́на; иселити се из стана вы́селиться или вы́ехать из кварти́ры; изгубити се из сећања исче́знуть из па́мяти б) с с їен.; из фабрике с фа́брики или с заво́да; допутовати из Украјине прие́хать с Украи́ны; вратити се из лова верну́ться с охо́ты; устати из постеље встать с посте́ли 2. у оgреgби времена а) из $c$ іен.; из дана у дан изо дня в день б) с $c$ їен.; из детињаства с де́тства; из почетка с нача́ла 3. у оgреgби начина, мере и сиееиена а) из $c$ їен.; пуцати из пушке стреля́ть из винто́вки; пити из флаше пить из буты́лки; викати из све снаге крича́ть изо всех сил б): викати из свег грла крича́ть во всё го́рло; знати из искуства знать по о́пыту; познавати из виђења знать по ви́ду или в лицо́ 4. y ogpegби начина и йовоgа а) из с їен.; рећи из уч- 
тивости сказа́ть из ве́жливости; учинити из зависти сде́лать из за́висти; из радозналости из любопы́тства б) с, от с йен.; из страха со стра́ху, от стра́ха; из очајања с или от отча́яния в) по с gāu.; оженити се из љубави жени́ться по любви́; из навике по привычке; из рачуна по расчёту; из ког разлога? по како́й причи́не? 5. у айрибуйској оgреgби (оgвијање) а) їен. без йреgл.; рукопис из XII века ру́копись XII века; наставник из руског језика преподава́тель ру́сского языка́ б) из с їен.; младић из радничке породице ю́ноша из рабо́чей семьи́ в) по $c$ gaū.; тројка из математике тро́йка по матема́тике; уџбеник из физике уче́бник по фи́зике.

Обрада предлога, као што се може закључити, захтева посебан приступ који је у основи синтаксички и настоји да представи колико је могуће потпунији опис синтаксичке спојивости. Он подразумева успостављање еквивалентности не толико на нивоу предлога као лексичких јединица, колико на нивоу конкретних значења која се испољавају путем предлошко-падежних конструкција.

ТЕРминологијА. Професор Станковић је у свом научноистраживачком опусу пажњу посвећивао и питањима терминологије. Детаљније бављење овом тематиком отпочиње у периоду Станковићевог учешћа у заједничком пројекту Срйскохрвайско-руски речник. Управо у оквирима српско-руске лексикографије, на примеру речника општег типа, превасходно су се одвијала и професорова терминолошка разматрања. У њима су сагледавани различити проблеми са којима се лексикограф сусреће приликом одабира и лексикографске обраде терминолошких јединица.

Одабир речи које ће бити заступљене у речнику спада у ред важних и не увек једноставних лексикографска питања. Иако је тачно да тип речника умногоме одређује и избор речи у њему, тиме се ипак указују само основна полазишта која, међутим, отварају низ неразрешених питања и задатака. Ситуација се додатно компликује када су ти задаци из домена једнојезичне лексикографије, и то полазног језика речника (као што је нпр. то био случај деведесетих година када није постао велики једнотомни нормативни речник српског језика). На тај начин професор Станковић издвојио је одабир речи као један од сложенијих проблема те врсте. Он је сматрао да дефинисање коначног одабира речи лексикограф не сме да заснива на сопственом језичком осећању и интуицији, нити по некритичком угледу на већ постојећа остварења двојезичне лексикографије, већ на конкретним и јасно одређеним критеријумима лингвистичког и екстралингвистичког карактера (Станковић 1999к: 75).

Међу критеријуме који су екстралингвистичке природе, или у себи садрже и екстралингвистичке елементе, он је навео најпре критеријум потребе корисника речника. Он има значајну улогу у одабиру лексике за речник, а самим тим и терминологије. Станковић сматра да терми- 
не треба бирати из терминолошких система широког круга научних и стручних области, премда је јасно да неће сви у подједнакој мери бити заступљени. Као дугогодишњи професор схватао је да ће речник имати важну функцију у настави, као и приликом учења и усвајања страног (руског) језика, те је сматрао природним да у речнику у знатој мери буду заступљене граматичка и лингвистичка терминологија.

Наредни критеријум, степен употребљивости речника, представља већи изазов. Српски језик нема фреквенцијске речнике, али лексикограф ипак има оријентире у виду школских енциклопдијских приручника и речника школске терминологије.

Приликом одабира одређеног термина треба водити рачуна о његовом карактеру и установити следеће: 1) да ли је изворног или интернационалног карактера, 2) да ли је вишезначан или не, 3) да ли се користи у више области или само једној, као и да ли осим терминолошког значења лексема има и неко општекњижевно, широко распрострањено значење, стога је правило избора према наведеном критеријуму Станковић (1999к: 76) дефинисао на следећи начин: „што је термин информативнији, то је и већа могућност његовог укључивања у речник".

Друштвени значај термина, под којим је Станковић заправо подразумевао његову актуелност, представља критеријум који не треба да буде занемарен приликом одабира термина у општем двојезичном речнику. Потребно је заступити термине из савременог друштвеног живота који су фреквентни у средствима јавног информисања, али и термине у сфери нових дисциплина у области науке и технике. Како састављање речника неретко прати и једна потешкоћа практичне природе - проблем ограничености простора, те ограниченог броја речи - професор Станковић (1999к: 76) изнео је став да предност треба дати савременој терминологији над архаичном лекиком, управо због актуелности и друштвене оправданости.

Критеријум диференцирања термина полазног и преводног језика носи лингвистички карактер. Професор је сматрао да у општи речник треба уврстити српске термине који у односу на еквиваленте у руском језику садрже неко диференцијално обележје, било да се ради о формалном или о семантичком плану. Како би се дати критеријум у потпуности и на адекватан начин реализовао, наша лексикографија би требало претходно да располаже добро и у потпуности обављеном конфронтационом анализом руске и српске терминологије у целини и у реализацијама појединачних терминолошких система (Станковић 1999к: 77). У том контексту треба имати на уму и следећа важна питања: проблем безеквивалентности, однос порекла термина једног и другог језика, диференцирање лексике страног порекла који се манифестују и у терминологији интернационалног карактера у два језика. 
Доиринос иррофесора Боіольуба Сйанковића лексикоірафским ирроучаваюима... 209

Диференцирања међу терминолошким јединицама интернационалног карактера завређују посебну пажњу. Дата диференцирања су „често танана и у лексикографској пракси занемаривана било ограниченим укључивањем такве терминологије (изостављање многих термина из речника правдало се тиме да је и у другом језику исти такав еквивалент, па је лексема кориснику речника разумљива, те нема потребе да јој се тражи тумачење у речнику), било поједностављеним успостављањем еквивалентног односа између термина двају језика који се слично или истоветно пишу или изговарају" (ibid).

Интернационални термини у два језика могу бити облички исти или приближно слични, али семантички неподударни. Семантичка неподударност могла се огледати у облицима обају језика, у већој или мањој мери, и то, према Станковићу (1999к: 78-81) превасходно у четири правца: 1) термини ступају у однос међујезичке хомонимије и паронимије (нпр. срп. акцелерација и рус. акселераиия / акиелерачия), 2) термин у српском језику има шире значење од одговарајућег руског еквивалента (нпр. руски термин вегетация има значење „раст и развој биљака", али не „биљке из одређеног краја” као српски вегетаиија), наредни правац је супротан од претходног и подразумева да 3) термин у српском језику има уже значење од одговарајућег руског еквивалента (нпр. уп. рус. ракешеа има значење „раст и развој биљака”, али не „биљке из одређеног краја" као српски вегетаu,ja), 4) разлике у погледу редоследа значења код вишезначних речи (нпр. уп. срп. pagujā̄op и рус. paguamop).

О интернационалним терминима професор је писао и са становишта формално-граматичких диференцирања. Наводећи да се одликују разноликошћу и вишеструкошћу, слично као што је случај и са лексиком страног порекла (чему је посветио и засебан рад Станковић 1969), класификовао их је у три групе. Прва се диференцирања односе на род (нпр. срп. абиойенеза ж = рус. абиогенез м, срп. кайоgа ж = рус. катоg м итд.), друга на развој суфикса, и то превасходно - -жж $=-a ж$, $-и з а м=-и з м,-и с \bar{u}(a)=-и с \bar{u}$ (уп. нпр. срп. йонажа = рус. тонаж), док трећа подразумевају гласовна диференцирања на нивоу корена термина за које професор Станковић наводи да су најчешћа следећа три: 1) х : г (нпр. срп. хияролиза = гияролиз), 2) у : в (неуроза = невроз), 3) т : ф (срп.

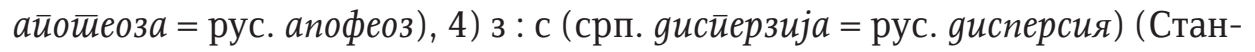
ковић 1999к: 80-81).

НормАтивистикА. Бавећи се различитим питањима из области српско-руске лексикографије, Богољуб Станковић бавио се и нормом српског књижевног језика у светлости двојезичних речника. У циљу подршке идеје о јединству и целовитости српскохрватског језика, лексикографија 
српског (српскохрватског) језика, једнојезична и двојезична, у значајној мери укључила је и признала варијантност у различитим правцима и односима. Притиснута том идејом, наука о српском језику одлагала је питања језичке норме, што је нашло негативан одраз и на двојезичну лексикографију. То се, како пише Станковић (19993: 65), могло огледати и у томе што ни крајем XX века није постојао једнотомни описни речник српског језика и готово ниједан ортолошки речник. „Свеукупна реалност последњих година на нашим просторима поменуто јединство свела је на благородну жељу и сан заљубљеника коме љубав није узвраћена и коме је крајње време да се од те опчињености ослободи, да српски језик омеђи онако како то реалност налаже, да за тај језик утврди норме са минималним варијантама, двострукостима и трострукостима" (ibid).

Пре него што приступи изради двојезичних речника, лексикограф најпре треба јасно да одреди свој став према питању варијантности. Он ће и током рада на речнику долазити у ситуацију да разрешава бројне нерешене проблеме књижевнојезичке норме српског језика, док ће његов став према одређеним нормативним питањима бити у одређеној мери детерминисан различитим чиниоцима (циљна група корисника речника, тип речника - активни, пасивни или активно-пасивни, фреквентност употребе речи у савременој комуникацији, развојна перспектива, економичност - лингвистичка и прагматичка и др.) (Станковић 19993: 66).

У погледу варијантности облика у изговору старог јата, професор Станковић (1999з: 67) наводи да има много оправдања да се у будућим двојезичним речницима користе само екавски облици. Најпре, такав

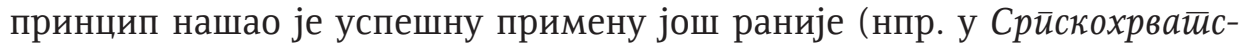
ко-руском речнику И. Толстоја из 1970. године и Руско-срйскохрвайском речнику у Станковићевој редакцији из 1988. године). Осим тога, професор изнети став објашњава и маргиналном заступљеношћу ијекавице у лексичком систему српског језика, нижим степеном лингвистичке и прагматичке економичности у односу на екавски лик, као и тиме да носиоцима српско-иностраног билингвизма она у изворима двојезичне лексикографије није потребна (ibid). На тај начин њено укључивање peзултирало би редудантним дуплирањем и нерационалним трошењем по правилу ограниченог речничког простора који може бити далеко прагматичније искоришћен за представљање лексичко-синтаксичке спојивости речи и исцрпнијег описа савременог лексичког фонда српског и страног језика.

Када је реч о варијантама заснованим на разликама у појединим гласовима, проф. Станковић сматра да лексикограф ту има мање дилема. Он сматра нерационалним и вишеструко неоправданим укључивање облика попут свећеник, кухарии, $а$, кемија, йлаћа, јер је сасвим јасно који је изговор доминантнији и аутентичније одражава реално језичко стање. 
У случајевима када разлике настају код творбених елемената и одговарајућих лексичких реализација и конкретизација, професор сматра да је такође довољно јасно које облике треба заступити а које не (нпр. асис-

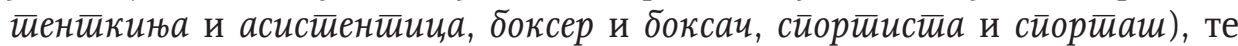
да би укључивање варијантних облика представљало узалудно губљење времена и нерационално трошење речничког простора (Станковић 19993: 67-68). Сличног је мишљења и за дилеме у одабиру географски маркираних лексема из парова попут воз и влак, хлеб и крух. Према Станковићу (2010а: 193-194) „неоспорно је да носиоци српско-иностраног двојезичја поздано владају неутралним и шире распрострањеним српским варијантама, те су способни да успостављају односе евкивалентности између варијаната ако им то говорна ситауција и околности употребе језика одн. речника налажу". Једини случај у коме Богољуб Станковић види оправданост заступљености обају облика јесте речник великог обима, пасивног типа, који би био намењен странцма и служио за превођење српских текстова на стране језике.

Разматрајући питања језичке норме, Станковић је такође писао о акцентима и дилемама које се тичу информација о прозодији у двојезичним речницима. Он је уочио три доминанте ситуације у том погледу: 1) лексика српског језика у иницијалној позицији по правилу се наводи са акцентом, што није случај са илустративним материјалом и српским преводним еквивалентима на десној страни речника, 2) сав руски језички материјал акцентован је по правилу у речницима са руским језиком, 3) у речницима са другим језицима прозодијске информације о њима изостају (Станковић 2010а: 195). Нормативна неуређеност прозодијског нивоа српског језика и прагматични разлози могу оправдати редуковање информације о српским акцентима и оставити лексикографу да да̂ или изостави дате информације на основу типа, карактера и намене речника (ibid). Станковић је сматрао да би „исцрпно представљање прозодијског нивоа српског језика имало пуно оправдање само у речницима активног типа намењеним инострано-српским билингвама (реалним или потенцијалним)", те да би циљ информација о прозодији био помагање странцу приликом усвајања одговарајућег изговора српских речи у свој укупности облика, на нивоу синтагме и реченице (ibid). Богољуб Станковић је сматрао да акценат не би требало да буде пропраћен варијантним облицима, већ да одговара савременом језичком стању и одражава изговор говорних представника српског језика данас (Станковић 1999з: 71).

Професор Станковић је тврдио да ће двојезични речници са више

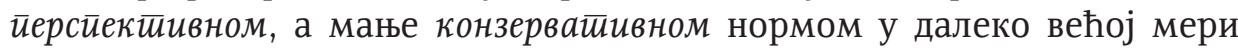
допринети двојезичној лексикографији, српском језику и развоју двојезичја где је један од језика српски (Станковић 2010а: 194). Његова раз- 
мишљања о норми српског језика свакако треба да буду незаобилазан оријентир приликом састављања двојезичних речника, тим пре што је тврдње које је износио у радовима износио и у реферату на симпозијумском заседању коме је председавао академик Павле Ивић. Он изложена опредељења том приликом није оспоравао, о чему сазнајемо из четврте фусноте Станковићевог рада „О актуелним питањима српске двојезичне лексикографије" (в. Станковић 2010а: 193).

ИстоРијА ЛЕКсикогРАФије. Једна од области где је професор Богољуб Станковић дао значајан допринос јесте и историја славистике. Ради се о питању које само по себи засигурно може бити (и завређује да буде) тема посебног рада. Историјом славистике Станковић се нарочито бавио током последње две деценије свога живота, што је умногоме природно, а посеб̆о интензивно током двехиљадитих година. Из тог разлога не чуди да је у професоровим радовима место нашла и историја лексикографије.

На међународном симпозијуму посвећеном доприносу руске емиграције српској и другим словенским културама Станковић је посветио рад лексикографском делу И. И. Толстоја. Поменути рад објављен је и коју годину касније увршћен у његове Лексикоіррафске ойлеgе (Станковић 1999ђ). Дати одабир није био случајан. Сагледавајући резултате српскоруске лексикографије у XX веку, Станковић (1999ђ: 83) констатује да се резултати у том домену своде готово на један речник, Толстојев Сербско-

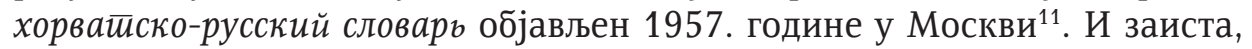
почев од Диферениијалної срйско-рускої речника Л. А. Мичатека из 1903. године, следила су различита српско-руска лексикографска остварења, у неједнакој мери успешна, али ниједна тако великог обима и степена употребе. Дати речник током читавог века представљао је незаобилазно средство које је широку употребу имало како у нашем образовном систему, мислимо најпре на наставу руског језика, тако и у преводилачкој пракси. Толстојев речник, с правом наводи Станковић (1999ђ: 88), обележио је читав век, а чији се посебан значај може видети када се у обзир узме податак да је И. Толстој био неко ко није имао редовно филолошко образовање и лексикографско занимање. Управо њему, овом истакнутом слависти, Станковић је посветио засебан рад у коме је представио

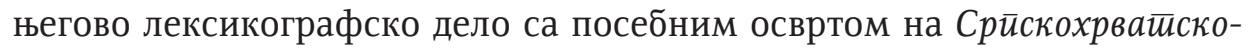
руски реиник и његову перпецију у нашој средини.

ЗАкључАк. Проф. др Богољуб Станковић оставио је иза себе богато наслеђе. Његова лексикографска истраживања руског и српског језика

${ }^{11}$ Овај речник у првом издању обухватао је око 50000 речи. Доживео је још четири издања, док је треће допуњено и исправљено. Дато издање из 1970. године обухватало је и већи број речи, 54000. 
значајно су допринела развоју и унапређивању лексикографске теорије и праксе. Расветљавањем различитих питања и проблема, превасходно у домену двојезичне лексикографије, професор Станковић оставио је велики траг у датој области. Многа његова запажања, конструкцијска решења и лексикографска остварења актуелна су и незаобилазна до данас, што може сведочити о значају Станковићевог дела. Својим прегалаштвом он је заузео посебно место у српској русистици и славистици, где се међу истакнуте посленике заслужено прибројава и његово име.

\section{Цитирана литература}

Буњак, Петар, Голубовић, Ана. „Биобиблиографија Богољуба Станковића”. Славистика XVI, 2012: 21-41.

Кончаревић, Ксенија. „Рецепција дела Радована Кошутића у послератној русистичкој лингводидактици код Срба : о шездесетогодишњици смрти". Славистика XIV, 2010: 323-335.

Кончаревић, Ксенија. „Лингводидактичко наслеђе професора Богољуба Станковића". [У:] К. Кончаревић (ур.) Трагом славистичких истраживања професора Богољуба Станковића. Београд: Филолошки факултет, 2018. (у штампи)

Пипер, Предраг. „О српској лингвистичкој русистици друге половине XX века”. [У:] К. Кончаревић (ур.) Универзитетска славистика: традиције, савремено стање, перспективе. Међународни научни зборник поводом 140 година Катедре за славистику Београдског универзитета = Университетская славистика: традиции, современное состояние, перспективы. Международный сборник научных статей, посвященный 140-летию Кафедры славистики Белградского университета, Београд: Филолошки факултет Београдског универзитета, 2017, 341-359.

Станковић, Богољуб. „О односу руске и српскохрватске лексике истог страног порекла". Pedagoška stvarnost 10, 1969: 652-659.

Станковић Богољуб. Интерференција у предикатским синтагмама руског и српскохрватског језика. Боград: Филолошки факултет, 1979.

Станковић, Богољуб. „Предговор”. [У:] Б. Станковић (ред.) Руско-српски речник. Нови Сад: Матица Српска, Будућност; Москва: Русский язык, 1998, 5.

Станковић, Богољуб. Лексикографски огледи. Београд: Славистичко друштво Србије, 1999.

Станковић, Богољуб. „Везници, везнички изрази и везничке речи у руско-српским и српско-руским речницима". [У:] Лексикографски огледи. Београд: Славистичко друштво Србије, 1999а, 89-95.

Станковић, Богољуб. „Двојезични речници и међусловенски билингвизам”. [У:] Лексикографски огледи. Београд: Славистичко друштво Србије, 1999б, $11-16$. 
Станковић, Богољуб. „Конфронтациона анализа и руско-српски речници”. [У:] Лексикографски огледи. Београд: Славистичко друштво Србије, 1999в, $17-23$.

Станковић, Богољуб. „Конфронтациони приступ синтагмама српског и руског језика са становишта двојезичне лексикографије". [У:] Лексикографски огледи. Београд: Славистичко друштво Србије, 1999г, 33-39.

Станковић, Богољуб. „Конфронтационо проучавање словенских језика и двојезични речници активног типа". [У:] Лексикографски огледи. Београд: Славистичко друштво Србије, 1999д, 25-31.

Станковић, Богољуб. „Лексикографско дело Иље Иљича Толстоја”. [У:] Лексикографски огледи. Београд: Славистичко друштво Србије, 1999ђ, 83-88.

Станковић, Богољуб. „Повратни глаголи у српско-руским и руско-српским речницима". [У:] Лексикографски огледи. Београд: Славистичко друштво Србије, 1999е, 41-49.

Станковић, Богољуб. „Предлози у будућем српско-руском школском речнику". [У:] Лексикографски огледи. Београд: Славистичко друштво Србије, 1999ж, 111-122.

Станковић, Богољуб. „Проблеми норме српског књижевног језика и двојезична лексикографија". [У:] Лексикографски огледи. Београд: Славистичко друштво Србије, 19993, 63-71.

Станковић, Богољуб. „Руски и српски предлози у речницима и настави”. [У:] Лексикографски огледи. Београд: Славистичко друштво Србије, 1999и, 97-109.

Станковић, Богољуб. „Стилистичке информације у речницима српског и руског језика". [У:] Лексикографски огледи. Београд: Славистичко друштво Србије, 1999ј, 51-61.

Станковић, Богољуб. „Терминологија у општем српско-руском речнику”. [У:] Лексикографски огледи. Београд: Славистичко друштво Србије, 1999к, 73-81.

Станковић, Богољуб. „Уместо закључка: перспективе лексикографског сучељавања словенских језика". [У:] Лексикографски огледи. Београд: Славистичко друштво Србије, 1999л, 129-132.

Станковић, Богољуб. „Уместо предговора: о актуелним питањима лексикографског сучељавања словенских језика". [У:] Лексикографски огледи. Београд: Славистичко друштво Србије, 1999љ, 5-9.

Станковић, Богољуб. „Школски руско-српски речници (Карактеристике и примена у настави". [У:] Лексикографски огледи. Београд: Славистичко друштво Србије, 1999м, 123-128.

Станковић, Богољуб. „О напоредном сагледавању српских и руских синтагми”. Јужнословенски филолог 56, 3/4, 2000: 1077-1083.

Станковић, Богољуб. „Обрада предлога у двојезичној лексикографији словенских језика : реално питање и оптималне могућности". [У:] Дескриптивна лексикографија стандардног језика и њене теоријске основе. Београд: САНУ: Институт за српски језик ; Нови Сад: Матица српска, 2002: 359363. 
Станковић, Богољуб. „Базични лексички ниво српског језика”. Славистика VII, 2003: 429-433.

Станковић, Богољуб. „О актуелним питањима српске двојезичне лексикографије". [У:] Славистика, русистика, србистика. Београд: Чигоја штампа, 2010a, 190-197.

Станковић, Богољуб. „О целесообразности формирования методологии изучения и методики преподавания русского языка как инославянского". [У:] Славистика, русистика, србистика. Београд: Чигоја штампа, 2010б, 162-166.

Станкович, Боголюб. „Один пока нереализованный проект: сербско-русский словарь". [В:] Б. Станкович (ред.) VI Международный симпозиум Проекты по сопоставительному изучению русского и других языков. Доклады. Београд: Славистичко друштво Србије, 2004, 174-178.

\title{
Срджан Петрович
}

\author{
ВКЛАД ПРОФЕССОРА БОГОЛЮБА СТАНКОВИЧА \\ В ЛЕКСИКОГРАФИЧЕСКИЕ ИССЛЕДОВАНИЯ \\ РУССКОГО И СЕРБСКОГО ЯЗЫКОВ
}

\section{Резюме}

Предлагаемая статья посвящена выдающемуся сербскому языковеду, доктору филологических наук, профессору Боголюбу Станковичу. Рассмотрен его научный и практический вклад в развитие лексикографии русского и серббкого языков. Выделены и проанализированы важнейшие аспекты его научно-исследовательской работы в области двуязычной лексикографии, а также самые значительные результаты и их актуальность на сегодняшний день.

Ключевые слова: Боголюб Станкович, лексикография, сопоставительные исследования русского и сербского языков, двуязычные словари, русско-сербская лексикография, сербско-русская лексикография 